\title{
UTILIZATION OF MOSQUES AS A PART OF EARLY WARNING SYSTEMS TO REDUCE FLOOD DAMAGES IN SAMARINDA CITY, INDONESIA
}

\author{
Riyan Benny Sukmara ${ }^{1,2}$, Ray Shyan $\mathrm{Wu}^{3}$ \\ ${ }^{1}$ Department of Civil Engineering, National Central University, Zhongli, Taiwan; E-mail: bennysukmara@itk.ac.id \\ ${ }^{2}$ Department of Civil Engineering, Institut Teknologi Kalimantan, Balikpapan, Indonesia \\ ${ }^{3}$ Department of Civil Engineering, National Central University, Zhongli, Taiwan; E-mail: raywu@ncu.edu.tw
}

\begin{abstract}
Samarinda City is one of the most attractive city in Borneo Island (Indonesia) and also as a capital city of East Borneo Province. The expansion of urban area becomes essential due to rapid population and housing demand. Base on the statistical report, the annual population growth rate is $0.018 \%$ from the year 2016-2017 with a total population of 843446 inhabitants. Many natural disasters occur in some area in this city, especially flooding. This natural disaster occurs almost every year, many people suffered and forced to evacuate. In 2018 there is 3 flood event with 28311 people was suffered and evacuated, and 5170 houses were flooded [1]. During the flood event, it was very possible to gain damages to their property and makes traffic stuck. One common way to reducing the damages is using Early Warning Systems (EWS). Early warning is a major element for disaster risk reduction, including damages. To prevent and mitigate the impact of a disaster, many countries had taken action to build various method of a public warning system. An effective early warning system focused on people-centered and comprises the following element, such as risk knowledge, technical monitoring and service, communication and dissemination of warnings, and community response capability [2]. Related to the existing condition which Samarinda is a Muslim-dominated city and obviously has a lot of a number of mosques. This is a good potency to develop an early warning system because every mosque has loudspeaker for echoing Adzan (Muslim prayer-calling). With this existing condition, the loudspeaker can be utilized as a flood outdoor-voice warning announcer. The aim of this study is to briefly introduce the strategy of dissemination early warning by utilizing mosques. The hope of early warning dissemination is giving enough time to the people to evacuate their property to reduce damages and possible to giving information to avoiding traffic stuck (in a certain location) due to flooding. The results of this study can be used as input for decision makers to develop effective flood management strategies and policies, especially in the case of an early warning system where not well-developed in Samarinda
\end{abstract}

Key words - flooding, early warning, damage, mosque

\section{Introduction}

Flooding is the most frequent natural disaster in the world [3] and most severe natural disaster often faces by humanity worldwide [4]. Flood disaster is a prominent issue threatening public safety, public property, social and city development.

Following the statement about flooding frequency, based on historical data, several studies have predicted an increase in flood hazard due to impact of climate change in the long term [5]. In range of 2008 and 2014, approximately 185.6 million people were displaced by natural disaster around the world with 55\% (about 102 million people), were due to flooding [6]. Flooding can be triggered by static natural circumstance such as geography, topography and river meandering. Dynamic natural phenomenon such as heavy rainfall, damming sea/tidal of main river, land subsidence and silting affected by sedimentation [7]. In Indonesia, flooding issues became worst problem because this occurs in many location, including rural and urban area. Over last 10 years, the annual report recorded the frequency of flood more than 500 flood event occurred in Indonesia every year, not except Samarinda City.

\section{Background of The Study}

"Are you a new comer in Samarinda?"

Samarinda has a long story of flooding problem until people in Samarinda said "are you a new comer in Samarinda?" when someone ask/talk about flooding problem. In 1998 history recorded huge flood event was occurred in that city and inundated thousands of houses. The flooding depth estimated 2-3 meter with duration approximately 1 week and caused 4 people loss they life [8]. This huge flooding caused by heavy rainfall and triggered the collaps of Benanga Dam. The rainfall recorded at that time (December 25 and 26, 1998) approximately $85.0 \mathrm{~mm}$ and $74.3 \mathrm{~mm}$, respectively [9].

Flood Event

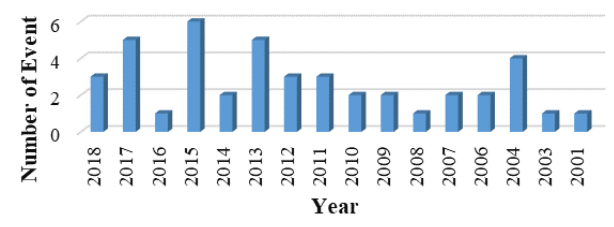

Fig. 1: Number of Flood Event in Samarinda

Nowadays, flooding issue in Samarinda cause critical problem for city development and communities. The flood caused significant losses on the infrastructure sector, 
economic sector and social sector. For infrastructure, it damages the city road, city park and public/private buildings such as school, offices, market, campuses and etc. Economic losses can be attribute to the exposure and vulnerability of assets. For the community sector, the flood damage they residential building, contents, children and youth cannot go to school and their loss of income due to cannot go to work, or they forced to close their shop during flooding. Based on the recorded data from Indonesian National Board for Disaster Management (BNPB), Samarinda has 44 flood event occurred from 1998 to 2018 with average number of flooded-houses approximately 3.171 houses every year [1] with estimated loss approximately IDR 250 billion (USD 17.5 million) per year [10].

Flooding problem grow exponentially in cities and megacities, since the disorderly occupation of the land, coupled with the size of the population, make it extremely complex to control and manage. In the most attractive city in Borneo likes Samarinda City, it is fundamental to have an urban master plan to the city shere a set of structural measures and non-structural measures minimize the impact of floods. In general, structure measures are engineering inventions that aim to reduce the risk of flooding whereas non-structural measure aim to reduce losses through better living of the population with floods. Sometimes, structural measure for flood control are not enough, the city need to deploy a number of non-structural measure such as flood warning system [11]. This system aims to reducing number of damage of floods that may cause impact in several area of the city.

Regarding to the strategy of flood warning system, we need to consider with the local wisdom of the study area. Samarinda is a Muslim-dominated city. Based on statistical data, there are $90,78 \%$ muslim population live in Samarinda [12]. So, obviously clear there are have a lot of mosque (Masjid) have been built in Samarinda. This a good potency to develop an early warning system by utilizing the Mosques as a part of it, because every mosque has a loudspeaker to echoing Adzan (Muslim-prayer calling). With this loudspeaker, we can utilize that for warning announcer. In this study, we tried to briefly introduce the potential of Mosques act as an outdoor warning system to prevent the community from floods impact.

Why the outdoor warning systems was chosen? Even though, nowadays the technology of warning system already developed such as SMS-based and mobile apps. The basic reason is the cost. To running the SMS-Based warning system, they need to join with the telecommunication provider and obviously it will be costly. Government need to allocate huge budget for that but the effectiveness still in doubt. Like-wise with the appsbased warning system, it very costly to develop the app. Apart from all budget problem, the people awareness is the main problem. Even we develop the app or disseminating the SMS (Short Message Service), it was difficult to force the people to download and install the app in their smartphone and also for the SMS we cannot guarantee that the people opening the message from Government. So, because of that reason, this study has choosing and interested to use the Outdoor warning system. Regarding to the cultural behavior, besides to echoing the Adzan, the mosque also was used to announcing the local government announcement and announce the obituary. So, people will try to listen carefully for the announcement from the mosque and also the level of public trust to the mosque still high. Early warning can only be effective if the people at risk trust the warning and know what to do whwn they receive a warning [13].

\section{Study Location}

Study location taken in Karang Mumus Sub-Basin (KMS) located in Samarinda Municipality, East Borneo Province, Indonesia with UTM coordinate 513575 $536589 \mathrm{E}$ and $9943710-9972162 \mathrm{~N}$. The population of this city approximately more than 820.000 inhabitans with annual population growth rate about $0.018 \%$. Total area of Samarinda City and KMS approximately $718 \mathrm{~km}^{2}$ and $365,27 \mathrm{~km}^{2}$, respectively. Based on statistics, topography of Samarinda dominated by lowland area with $42,77 \%$. It has elevation range +7 to $+25 \mathrm{~m}$ and $20,11 \%$ have elevation below $+7 \mathrm{~m}$ mostly located in the city center [14]. Based on the statistical data, the average annual rainfall in Samarinda approximately more than $2600 \mathrm{~mm}$ [14].

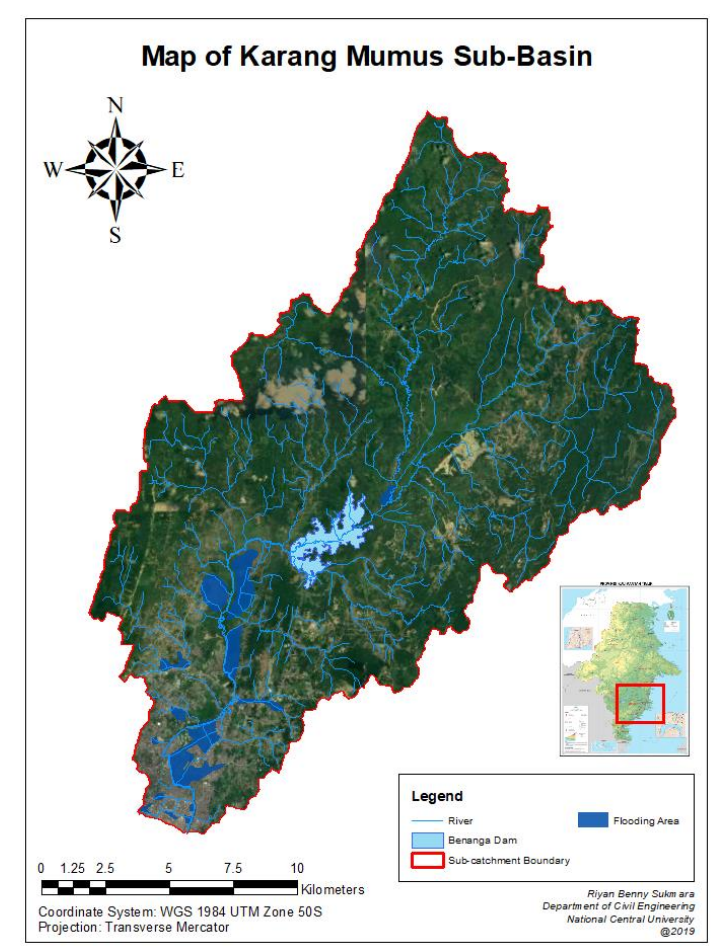

Fig. 2: Location of Study Area (flooded area provided by Department of Public Works in Samarinda)

\section{Objective and Methodology}

The objective of this study is to briefly introduce the utilization of mosques as an outdoor flood warning system in the framework of reducing flood damage in Samarinda city. To achieve the objective, literature survey was 
conducted to provide information about outdoor warning system. Hydrological analysis was conducted by using Hydrologic Modeling System (HEC-HMS) to obtain the flood discharge and flood hydrograph.

For the utilization of mosque, we analyzed the mosque location and dissemination coverage area of each mosque.

\section{Result dan Discussion}

\subsection{Current Flood Issue in Samarinda}

The city area is located in the downstream of Karang Mumus River and also connected with Mahakam River (one of biggest and longest river in Indonesia). The relatively-flat topography makes Samarinda very vulnerable to flood. The fast growing of population, force people to build new residential area and change the land cover. This process has inducing the increase of runoff coefficient. Regarding to the high rainfall intensity, the land use change will induce the increasing runoff discharge and makes the flood more severe. The most complicated flood problem is a lot of people live along river bank
Government was form the team for relocating community along Karang mumus river. In this program, there are 2591 household force to relocate and will be relocated gradually. Government have prepared new residential area for them. Until 2017, total of households need to relocate about 3.915 but only 1356 was relocated and this program also constrained due to change of national regulation, where Government was prohibited to give grants by using National Budget (APBN) for compensation of relocatedhoushold.

In 2014, the management regulation of Karang mumus River was changed from Local and Regional government to National Government. It was good enough in regulatory purpose and Karang Mumus become a national priority. But in the other hand, now the local government cannot involve deeper in the Karang mumus management.

According to the new regulation, so, the Regional or Local government can choose the non-structural approach to increase the involvement of flood management, such as developing community-based early warning system to help people secure their property from flood.

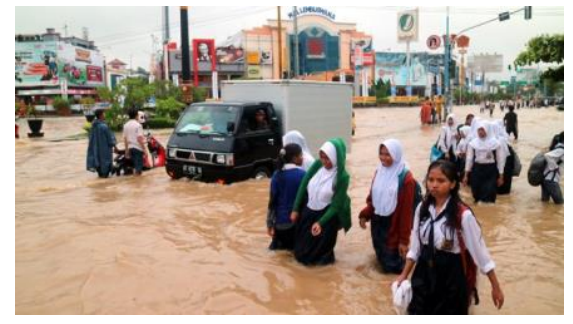

(a)

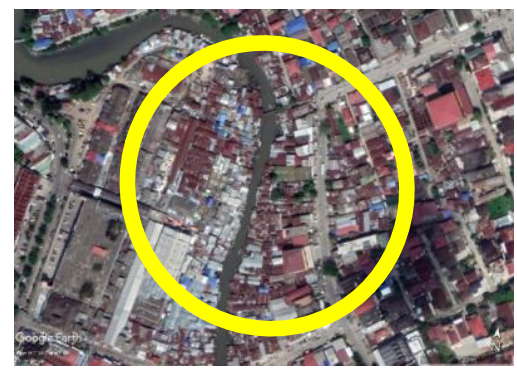

(b)

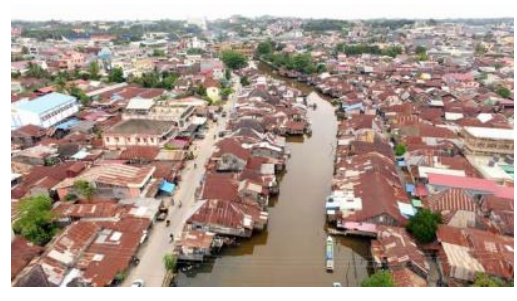

(c)

Fig. 3: (a) Flooding in Samarinda; (b) Top view of Residential area on along the river bank; (c) Semi-permanent house in the river

(Figure 3). This practices cause the constriction of the river and finally will decrease the river capacity.

Related with river bank settlement, it was not easy to relocating the people. They already live there from long time ago and the history said the indigenous people have cultural behavior that they cannot live far away from river and some area was claimed as customary land. Government was tried to developing relocation program to clearing the river bank. In 1993 Samarinda Government was started the relocation program by forming the counseling team for relocation. Continue to 1997, the

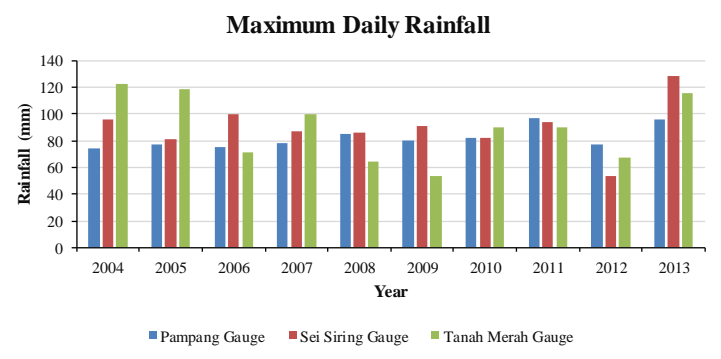

Fig. 4: Maximum Daily Rainfall

\subsection{Hydrological Analysis}

In the hydrological analysis, we can define the maximum daily rainfall from 3 gauges inside Karang Mumus Sub-basin, there are Pampang Gauge, Sei siring Gauge, and Tanah Merah Gauge. The calculation was used observed rainfall data from 2004 - 2013 (Figure 4).

To define the rainfall for each return period, we can obtain from 20 subsub-basin. Rainfall-runoff analysis was conducted by each Subsub-basin to find the discharge. For rainfall distribution, this study chooses 3 different distribution method, such as Normal (Weibull), Gumbel

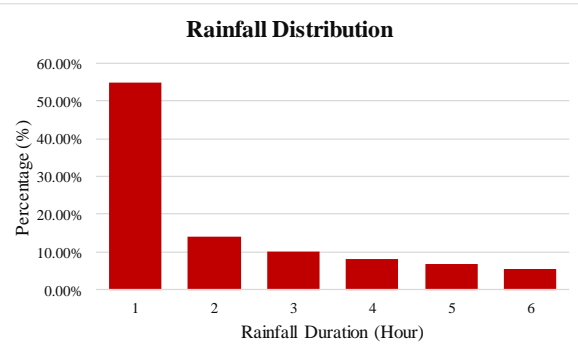

Fig. 5: Rainfall of Return Period 


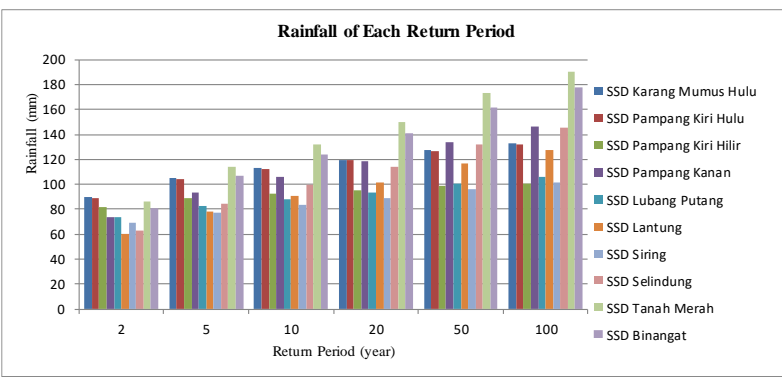

(a)

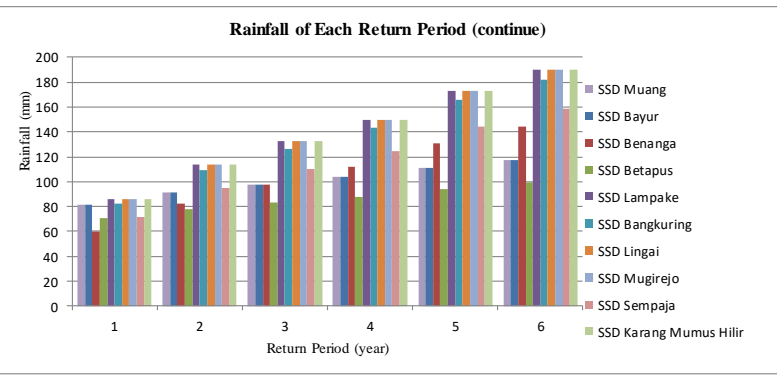

(b)

Fig. 6: (a) Rainfall of Return Period; (b) continue

distribution and Log Pearson Type 3 and tested by ChiSquared test and Kolmogorov-Smirnov test. The result shown in Figure 6.

For simulating discharge, this study used an assumption to developing the hydrograph. Due to limitation of observed hourly rainfall, we assume that the maximum duration of daily rainfall in 6 hours. By following Mononobe folmula, we can obtaine the percentage of rainfall distribution in each hour:

$$
I_{t}=\frac{R_{24}}{T}\left(\frac{T}{t_{c}}\right)^{2 / 3}
$$

where $I_{t}$ is the rainfall intensity in $\mathrm{mm} /$ hour for a rainfall duration $t, R_{24}$ is the 24-hour rainfall. The result shown in Figure 5.

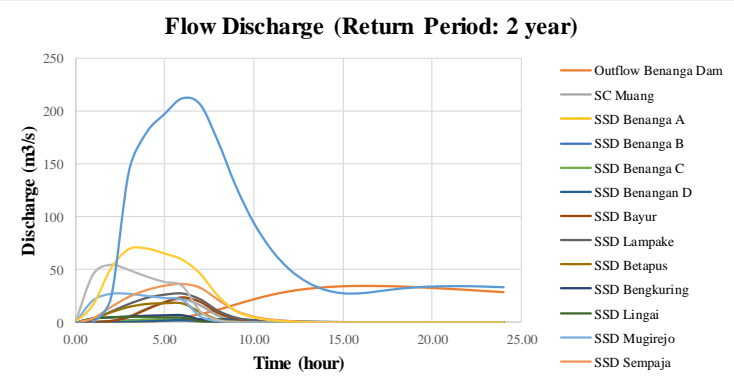

(a)

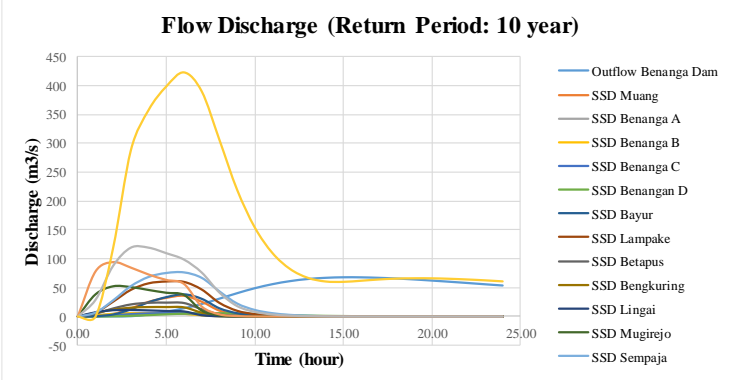

(c)
To obtain the discharge value, this study was using HEC-HMS and choose SCS Curve Number as a runoff simulation method and the result shown in Figure 7.

Based on the calculation above, the observed maximum daily rainfall in each year (Figure 4) spread up in range $53.9 \mathrm{~mm}$ to $128.5 \mathrm{~mm}$. Those rainfalls are equal with 2 years to 5 years return period rainfall.

Regarding to the recorded severe flood in 1998 and 2008, historical data recorded the rainfall in June 9 and December 26, 1998 were $85 \mathrm{~mm}$ and $74 \mathrm{~mm}$, respectively. In beginning of November 2008, rainfall has recorded 57.5 $-70 \mathrm{~mm} /$ day [9]. By following the result of simulation, these severe flood can be categorized as a rainfall of 2 years return period.

The obtaining calculation of discharge, we can know that the lag time between the simulated peak rainfalls and peak discharges are very diverse. For the subsub-basin, the lag time diverse in range $1-5$ hours but for the cumulative discharge (in the downstream) ranged between $6-7$ hours.

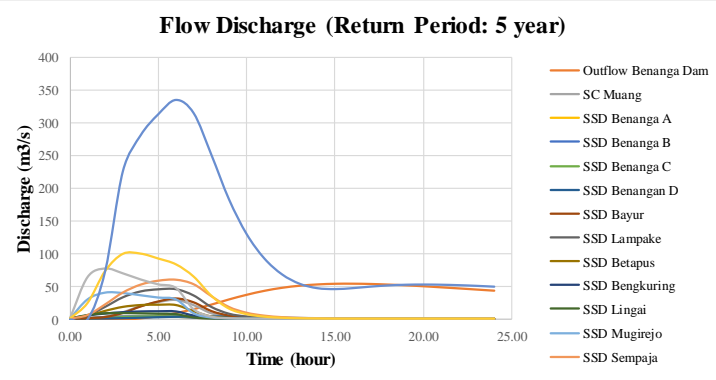

(b)

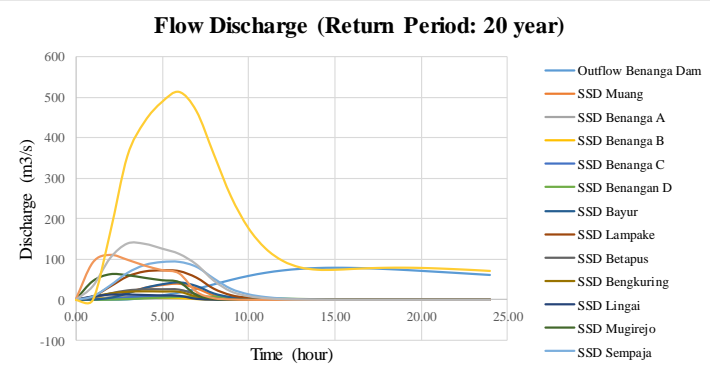

(d)

Fig. 7: Flow Discharge: (a) 2 years; (b) 5 years; (c) 10 years; (20) years 


\subsection{Flood Warning}

Flood warning systems are developed with the fundamental aim of increasing safety and reducing the harmfull effect of floods (reffere to as "damages" or "losses") [15]. The basic benefit of local flood warning program is an increase lead time for watch and warnings at locations subject to flood risk. The information can be used to predict whether a flood is about to occur, when it will arrive, and how severe it will be [16]. Providing warning service recognizes that at some point a rainfall event will

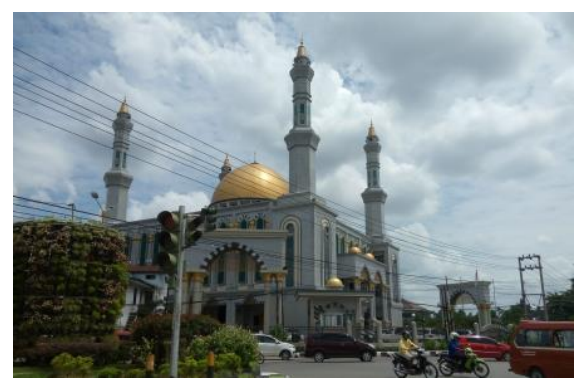

(a) convalescents and other requiring help

- Establish traffic control to facilitate and prevent inadvertent travel into hazardous areas

- Deploy fire and rescue service for continued protection.

When enough time is provided, it can also often be put to use to reduce property damage including:

- Moving vehicles and equipment from low areas

- Relocating or stacking contents of private structures

- Shutting down motor and pumps to prevent damage

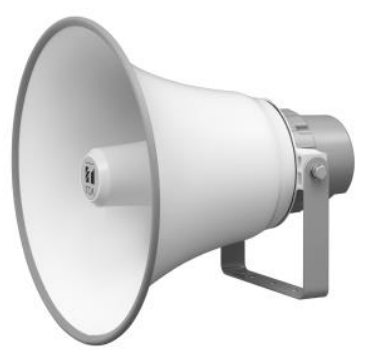

(b)

Fig. 8: (a) Typical of Mosque in Samarinda (Masjid Al Ma'ruf); (b) Typical outdoor loudspeaker used in mosques

occur that will exceed any surface water management arrangements and provide an option to limit the resulting damage [17] because the extent of losses avoided as a result of a warning is the key measure of warning system effectiveness [15]. The basic part of a flood warning program are:

- The flood warning systems, including equipment, people, and procedures for recognizing an impending flood and disseminating warnings

- A prepared plan of action to be taken before and during flood

- Arrangement for updating and maintenance of equipment and plans

The local flood warning programs can be extremely and significantly effective. Those now in use have been credited with saving scores of lives and preventing millions of dollar damages [16]. A properly working flood forecasting, warning and response system give property owners, floodplain residents and responsible authorities time to respond to a flood threat before flooding occurs [18].

Warning time is a critical factor in mitigating flood losses. The more lead time available for appropriate action, the greater damage reduction can be achieved [19]. Timely collection of more detailed information on local rainfall and stream levels allow more accurate and reliable prediction of flood. Advance knowledge about impending flood can be used to:

- Warn low-lying areas to evacuate

- Schedule closure of school and transportation of student

- Curtail electric and gas service to prevent fire and explosions

- Provide evacuation assistance to invalids,
- Initiating flood fighting efforts

- Establishing security to prevent looting

Regarding to the result of hydrologic simulation, we can consider with lag time to provide early warning for time allocation before the peak discharge and flood occurs. To deliver the effective of flood early warning, we can adopt the stage of delivering warning from Warner et al [20]:

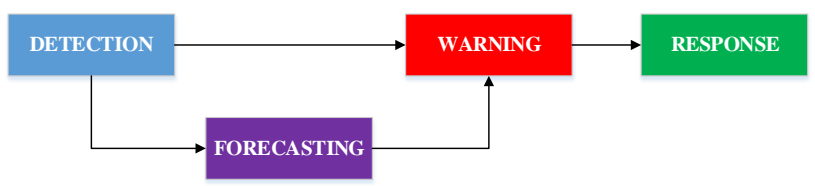

Fig. 7: Stages in the delivery of effective flood warning

In range of the lag time, we can develop the rainfall threshold to define and categorize the warning stage. According to the warning stage, we can also consider with the predicted duration of coming flood, depth of flood or the effect of the flood.

\subsection{Dissemination of Flood Warning}

Warning people about coming floods constitutes one of the most valuable and important tools in the flood management kit [21]. Flood warning may need to be issued to public, emergency services, local authorities and other with an interest in when and where flooding is likely to occur, or who are involved in the emergency response. In terminology od dissemination techniques can be broadly separated into indirect methods, community based methods, and direct methods [22]. Some example of these techniques include:

- Indirect methods: television, radio, Internet, telephone help line, newspapers or social media. 
- Community Based Method: sirens, fixed, mobile or helicopter loud hailers, megaphones and public address systems, bells, storm cones, flags, cascade systems, motorcycles, billboard/sign (electronic/manual), road barrier, flood wardens

- Direct Method: telephone, cell phone, door knocking, fax, pagers, two-way radio, email, leaflet drops, mobile apps.

Dissemination is based on the number of people initially notified by warning technology and by informal notification process. Some of recent work suggests the most effective waring systems have indoor and outdoor components [23]. Figure 9 shows that specialized warning divices are capable of more rapid dissemination of a warning than the media can achieve.

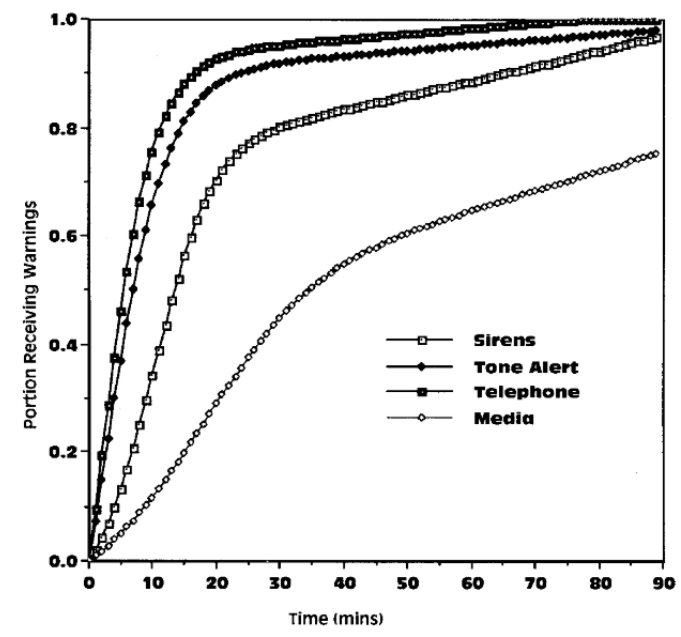

Fig. 9: Average Dissemination Time for Alternative Warning Systems Technology (Rogers and Sorensen 1988)

For flood warning dissemination technique in this study, we consider with the local wisdom, where Samarinda city has a lot of mosques which it can be an outdoor warning system. Why we choose this, because this facility has been provided and no need to build new tower to places the Loudspeakers.

In general, every mosque in Samarinda has an outdoor loudspeaker which in the daily used for echoing Adzan (Muslim Prayer-calling). It is good potential to utilized as warning devices like a siren. Even, the better than siren because the loudspeakers have voice communication capabilities which are allow the users to disseminate a warning message in addition to an alerting sound before and/or during emergency event [24]. The loudspeaker mostly located on the top of mosque building or tower, with elevation ranged from 8 to $20 \mathrm{~m}$ or more, depends on the height of the tower or mosque.

In Samarinda there are more than a hundred Muslim prayer facilities, including Mosque and Mushalla (small scale mosque). Based on the data from Ministry of Religion of Republic Indonesia, there are 370 mosques was registered in Samarinda [25]. So, according to the city area, the density of mosque 0,51 mosque $/ \mathrm{km}^{2}$ or there has 1 mosque in every $2 \mathrm{~km}^{2}$. The location of the mosque is spread throughout in the whole of Samarinda area.

In this study we analyze the mosque which located in the Karang Mumus basin. By manually check on the google earth to find the coordinates of mosques, the we use ArcGIS to plot the mosque in the map. The analyze obtained 120 mosques located in the Karang-Mumus basin and mostly located spread throughout the city center area (see Figure 9).

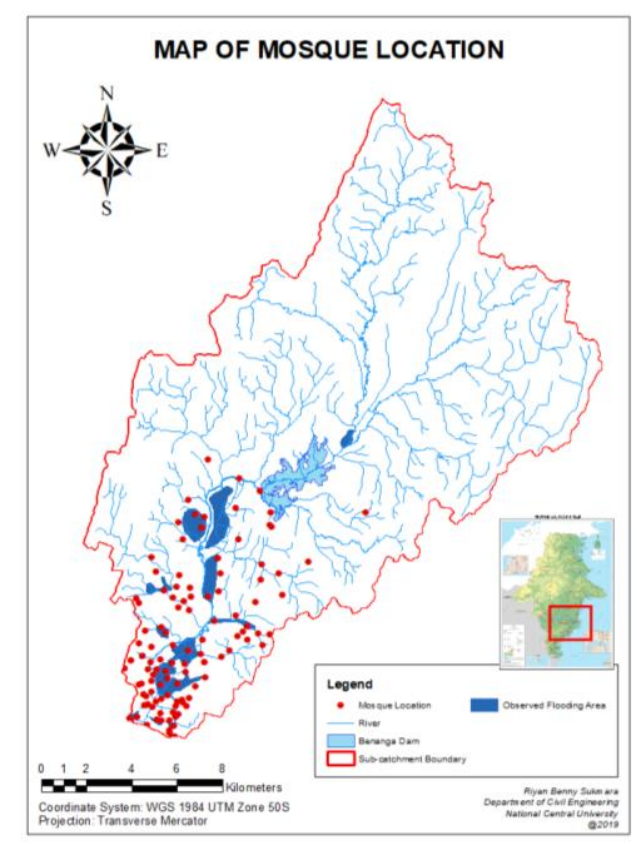

Fig. 10: Location of Mosque in Karang Mumus Basin

Following the goal of the warning dissemination which the warning announcement should be heard by the community, we were analyzed the coverage area by following the Federal Emergency Management Agency (FEMA) regulation [26].

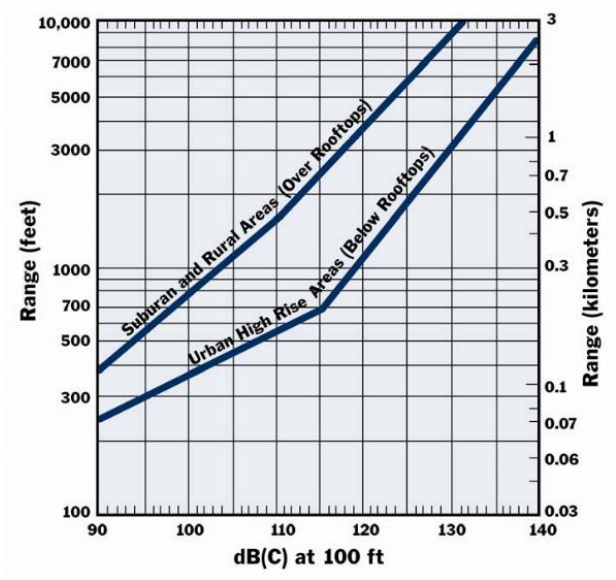

Fig. 11: Rate output of Warning Device in dB at 100ft (F-1)

This study has used an assumption that all the mosque has used the same typical loudspeaker. Based on the 
specification, the loudness power is $120 \mathrm{~dB}$ and FEMA was analyzed that the range of coverage area of hearing is 3700 $\mathrm{ft}(1.1 \mathrm{~km})$. Due to the location of the Karang Mumus basin relatively flat, we assume that no terrain blocking.

By using ArcGIS software, we plot the mosque location and following the rules developed by FEMA we obtain that the coverage area of each mosque is circle. After we know the coverage area, we have been plot the coverage area of the mosque.

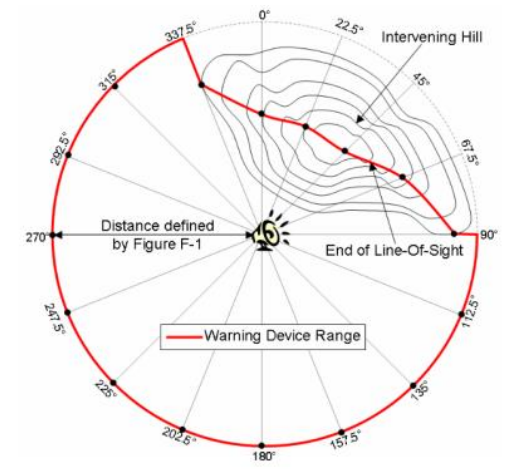

Fig. 12: Typical outdoor loudspeaker used in mosques

Based on the plotting result (see Figure 13), we can see the coverage area of outdoor warning systems were coverage almost whole area of the observed flooding location in the city center (area colored dark blue). For flooding location on the north area, there are no mosque located in that location.

With known of coverage area, we assume that the people will hear the dissemination of flood warning and can take responses to secure their property and content. Finally, the goal of flood damage and loss reduction can be achieved.

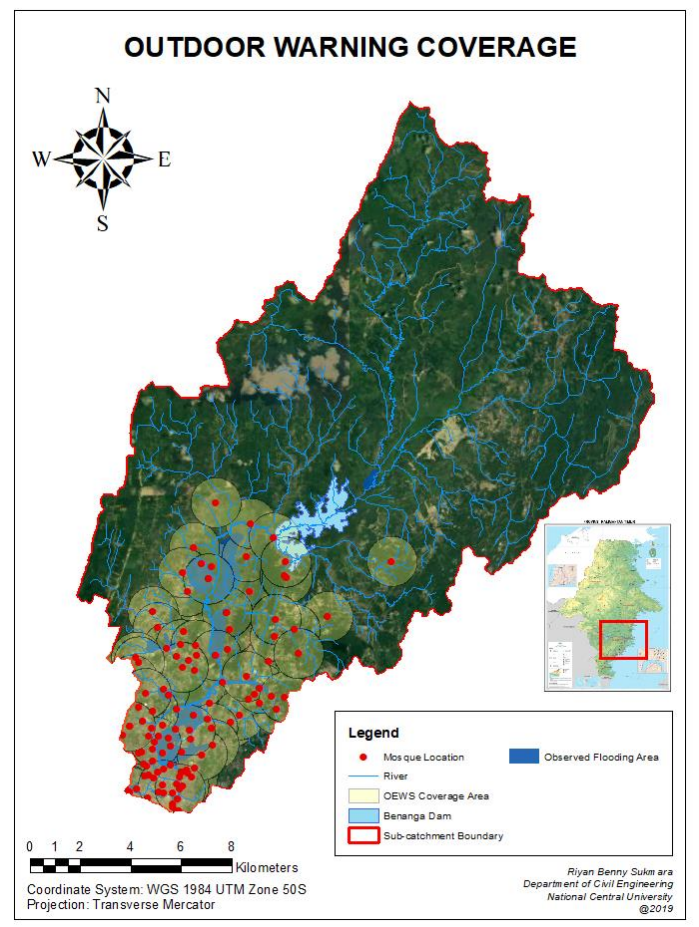

Fig. 13: Coverage area of Outdoor Warning Systems

\subsection{Role Play of Warning Communication}

For the role of warning communication network, this paper suggest the announcement should be guided by the weather bureau or Municipality Government. So, the information should be clear first before announced to the community.

The current condition, mostly of mosques in Indonesia has at least one person who has authority to manage and control the Mosques 24 hours, the person called "Marbot Masjid". This person can be the key person to disseminate the flood announcement from City Authority.

The communication network can be started from Monitoring station as the authority of weather monitoring (for instance: weather bureau [BMKG] or Dept. of Public Works) and giving the information about current weather condition and forecasted weather to Decision maker (City Authority). After the process of decision making, the final decision of warning will deliver to mosques (as announcer) and finally announce to community. Delivering the information can be used phone-call, short-messageservice, private frequency radio or mobile messaging apps. Due to avoiding the bad connection of the internet in the several areas in the city, the used of Text messaging or phone-call most effective than using mobile group messaging apps (i.e. What's-app group or Line App group) to communicating warning from government to Mosque authority.

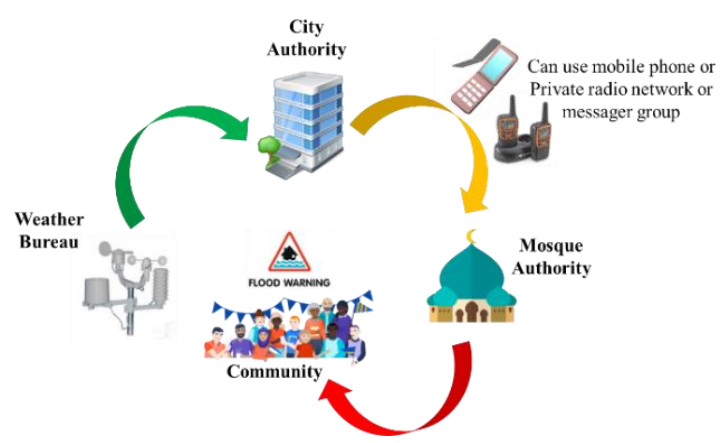

Fig. 14: Flood Warning Communication network

\section{Summary and Future Works}

This paper sets out to address the challenge of the flood damage reduction in Samarinda by promoting the early warning systems, especially for outdoor warning systems. To do this, an analysis to estimate the rainfall intensity and peak flood discharge is needed. The result in this study has obtained the severe flood in Samarinda induce by rainfall which is equal with 2-years and 5-years rainfall intensity and also the daily maximum of the rainfall in karang mumus basin is ranged from 2-years to 5-years rainfall return period. From this study, the lag time of peak discharge range from 5-6 hours from maximum rainfall occurring-time. So, this can be used as allocation time for disseminating of early warning and give several time to the community to securing their property and contents.

This study was obtained the coverage area of the outdoor warning system by utilizing the existing mosques 
in the Karang Mumus basin. The distribution of mosque locations has covered approximately $45 \%$ of the total area of Karang-Mumus basin and covered locations mostly located in the city center. In the communication network of flood warning, this study suggests to the Local Government (Samarinda City Authority) act as the main decision maker to announce the warning systems.

Of course, some limits have been recognized in this study, such as the detail of the flood simulation in hydraulic scope and the detail of damage estimation due to the flood event. Due to the limitations, this research was ongoing research and need a lot of improvements. For the future works, the study will consider with the effect of land use change to the behavior of the flooding process, such as increasing discharge, changing of the lag time and the distribution of the flooded area. Performing the analysis for estimating flood risk area and develop the flood risk map. For damage estimation, future study will conduct a deep analysis of the development of depth-damage curve for Samarinda city following the change of updated currency inflation. Furthermore, the early warning strategy will be improved with an update method which can increase the performance of flood early warning systems and considers with rainfall threshold estimation, so we can define a certain stage of the flood warning and also develop the suggested policy for the flood management in Samarinda. Relating to the flood warning dissemination, the future work will try to improve the flood warning communication network and validate the coverage area of outdoor warning systems. For enlarging the coverage area of the outdoor warning system, we consider involving the Mushalla (small scale mosque) to cover the rural area. Moreover, to increase the effectiveness of flood warning dissemination and improving the damage reduction, we also consider to involving the social media to targeting the youth generation and asses the effectiveness of it. To assess the effectiveness of warning system to the community and damage reduction, future work could be need to conduct the survey of it.

\section{References}

[1] InaRISK, "Data Informasi Bencana Indonesia," 2019. [Online]. Available: http://dibi.bnpb.go.id/. [Accessed: 29-Mar-2019].

[2] UNISDR, "Developing Early Warning Systems: A Checklist," in EWC III Third International Conference on Early Warning, 27-29 March 2006, 2006.

[3] A. K. Jha, R. Bloch, and J. Lamond, Cities and Flooding: A Guide to Integrated Urban Flood Risk Management for the 21st Century, vol. 52, no. 5. Washington DC, USA: The World Bank, 2012.

[4] S. Samanta, C. Koloa, D. Kumar Pal, and B. Palsamanta, "Flood Risk Analysis in Lower Part of Markham River Based on Multi-Criteria Decision Approach (MCDA)," Hydrology, vol. 3, no. 3, p. 29, 2016.

[5] IPCC, Climate Change 2013: The Physical Science Basis. Contribution of Working Group I to the Fifth Assessment Report of the Intergovernmental Panel on Climate Change. Cambridge, United Kingdom: Cambridge University Press, 2013.

[6] iDMC, Global estimates 2015: People Displaced by Disasters. Oslo, Norway: Norwegian Refugee Council, 2015.

[7] BNPB, Risiko Bencana Indonesia. Jakarta, Indonesia: Badan
Nasional Penanggulangan Bencana (Indonesian National Board for Disaster Management), 2016.

[8] N. N. I. Pramadewi and A. P. Rahardjo, "Analisis Hidraulika Banjir Akibat Keruntuhan Bendungan (Studi Kasus Bendungan Lempake, Kota Samarinda)," Universitas Gajah mada, 2014.

[9] Zulfakar, S. Soetomo, Suripin, and I. Buchori, "Pemodelan Optimasi Guna Lahan untuk Pengendalian Banjir Perkotaan (Studi Kasus: Kota Samarinda, Provinsi Kalimantan Timur)," Universitas Diponegoro, 2013.

[10]D. E. Pardede, "Kerugian Warga Samarinda Akibat Banjir 250 M Pertahun," Tribun Kaltim, 2014. [Online]. Available: http://kaltim.tribunnews.com/2014/05/29/kerugian-wargasamarinda-akibat-banjir-250-m-pertahun. [Accessed: 28-Mar-2019].

[11]M. T. L. Barros and F. Conde, "Urban Flood Warning System Social Benefits," in World Environmental and Water Resources Congress 2017, 2017, pp. 642-653.

[12]BPS Samarinda, Samarinda in Figure. Samarinda, Indonesia: Badan Pusat Statistic (BPS) Kota Samarinda, 2018.

[13]H. Kreibich, M. Müller, K. Schröter, and A. H. Thieken, "New insights into flood warning reception and emergency response by affected parties," Nat. Hazards Earth Syst. Sci., vol. 17, no. 12, pp. 2075-2092, 2017.

[14]R. B. Sukmara, R. Wu, and Ariyaningsih, "Analysis of Flood Discharge Reduction in Karang Mumus River, Samarinda City, Indonesia," in PAWEES 2017 International Conference, Sustainable Water and Environmental Management, 2017.

[15]D. Molinari and J. Handmer, "A behavioural model for quantifying flood warning effectiveness," J. Flood Risk Manag., vol. 4, no. 1, pp. 23-32, 2011.

[16]NOOA, Flood Warning Systems Manual. Silver Spring, Maryland, United States: National Oceanic and Atmospheric Administration, 2012.

[17]FEMA, CRS Credit for Flood Warning Programs. Indianapolis, USA: Federal Emergency Management Agency, 2006.

[18] J. S. Verkade and M. G. F. Werner, "Estimating the benefits of single value and probability forecasting for flood warning," Hydrol. Earth Syst. Sci., vol. 15, no. 12, pp. 3751-3765, 2011.

[19]R. H. Falconer, D. Cobby, P. Smyth, G. Astle, J. Dent, and B. Golding, "Pluvial Flooding: New Approaches in Flood Warning, Mapping and Risk Management," J. Flood Risk Manag., vol. 2, no. 3, pp. 198-208, 2009.

[20]M. G. F. Werner, J. Schellekens, and J. C. J. Kwadijk, "Flood Early Warning Systems for Hydrological (Sub) Catchments," Encycl. Hydrol. Sci., 2005.

[21]C. Keys and M. Cawood, "Identifying and reducing inadequacies in flood warning processes: An Australian perspective," J. Flood Risk Manag., vol. 2, no. 3, pp. 190-197, 2009.

[22]K. Sene, Flood Warning, Forecasting and Emergency Response. United Kingdom: Springer International Publishing, 2008.

[23] J. H. Sorensen, "Hazard Warning Systems: Review of 20 Years of Progress," Nat. Hazards Rev., vol. 1, no. 2, pp. 119-125, 2000.

[24]E. D. Kuligowski and K. Wakeman, NIST Technical Note 1950 Outdoor Siren Systems : A review of technology, usage, and public response during emergencies. National Institute of Standards and Technology, U.S. Department of Commerce, 2017.

[25]Kemenag, "Sistem Informasi Masjid Seluruh Indonesia," 2018. [Online]. Available: simas.kemenag.go.id. [Accessed: 29-Mar2019].

[26]FEMA, Outdoor Warning Systems - Technical Bulletin (Version 2.0). Washington DC, United States of America: Federal Emergency Management Agency, 2006. 


\section{Author information}

Riyan Benny Sukmara
- Graduated from Master degree of Department of Civil Engineering, Institut Teknologi Sepuluh
Nopember (ITS) Surabaya, Indonesia
- PhD Student in Water Resources Division, Department of Civil Engineering, National Central
University, Taiwan
Lecturer in Institut Teknologi Kalimantan, Balikpapan, Indonesia
- $\begin{aligned} & \text { Research topics: Flood damage reduction strategy in Samarinda City, Indonesia } \\ & \text { email: bennysukmara@itk.ac.id } \\ & -\end{aligned}$
Phone number: +886 986 481 202
Ray-Shyan Wu (吳瑞賢)
$-\quad \begin{aligned} & \text { Graduated from Doctoral Degree, Department of Civil Engineering, Cornell University, USA } \\ & \text { Distinguish Professor, Water Resources Division, Department of Civil Engineering, National Central } \\ & \text { University, Taiwan } \\ & \text { email: raywu @ ncu.edu.tw }\end{aligned}$

